\title{
SOSIALISASI PENGGUNAAN APLIKASI GOOGLE SEBAGAI PENUNJANG PELAYANAN UPT PERPUSTAKAAN DIMASA PANDEMI COVID-19
}

\author{
Roki Hardianto ${ }^{1}$, Junaidi ${ }^{2}$, 3. Eddissyah Putra Pane ${ }^{3}$ \\ 1,2,3 Universitas Lancang Kuning, Pekanbaru, Indonesia \\ Jalan Yos Sudarso KM. 08 Rumbai, Pekanbaru-Riau, (0761) 53108 -53236 \\ email.roki@unilak.ac.id, junaidi@unilak.ac.id, jugulspane@gmail.com
}

\begin{abstract}
Abstrak: Kegiatan ini dilaksanakan sebagai wujud keprihatinan terhadap layanan UPT Perpustakaan Universitas Lancang Kuning terhenti selama pandemic Covid-19. Layanan yang biasanya dilakukan secara manual / tatap muka terpaksa dihentikan sementara. Untuk membantu layanan tetap dilaksanakan secara daring maka team Pengabdian Kepada Masyarakat melakukan training kepada paguyuban pustakawan Universitas Lancang Kuning dengan topik pengenalan dan pemanfaatan aplikasi google dalam pelayanan perpustakaan. Kegiatan dilaksanakan selama 1 hari penuh dengan metode tatap muka dan praktek langsung penggunaan aplikasi google. Kegiatan dilaksanakan di ruangan multimedia UPT Perpustakaan Universitas Lancang Kuning yang dihadiri oleh seluruh pustawan. Pustakawan diajarkan cara membuat google form sebagai wadah pengurusan Surat Bebas Pustaka bagi mahasiswa. Serta pustawan juga diajarkan mendigitalisasi arsip perpustakaan agar terhindar dari resiko kehilangan data. Kegiatan ini dilakukan pengukuran pemahaman pustakawan terhadap materi training sebelum memulai kegiatan dan setelah selesai kegiatan dilaksanakan. Dengan kegiatan ini pustakawan dapat memberikan pelayanan secara daring tanpa mahasiswa datang ke perpustakaan. Team pengabdian melakukan publikasi terhadap kegiatan dilaksanakan dalam bentuk berita, publikasi jurnal ilmiah dan membuat buku manual.
\end{abstract}

Kata Kunci: covid-19, google, perpustakaan, unilak

\begin{abstract}
This activity was carried out as a form of concern for the service of the UPT Library at the Lancang Kuning University which was stopped during the Covid-19 pandemic. Services that are usually done manually / face-to-face had to be temporarily suspended. To help the service continue to be carried out online, the Community Service team conducts training to the Lancang Kuning University Librarian Association on the topic of introducing and utilizing Google applications in library services. The activity was carried out for 1 full day with face-to-face methods and direct practice using the Google application. The activity was carried out in the multimedia room of the Lancang Kuning University Library, which was attended by all librarians. Librarians are taught how to create a google form as a forum for administering Library Free Letters for students. Librarians are also taught to digitize library archives in order to avoid the risk of losing data. This activity is carried out by measuring the librarian's understanding of the training material before starting the activity and after the activity is carried out. With this activity librarians can provide services online without students coming to the library. The service team publishes activities carried out in the form of news, scientific journal publications and makes manual books.
\end{abstract}

Keywords: covid-19, google, library, unilak

\section{Pendahuluan}

\section{Analisis Situasi}

Semenjak di galakkannya Revolusi Industri 4.0 dan menuju Revolusi Industri 5.0, pemerintah indonesia semua bidang dalam pemerintahan telah melakukan perbaikan - 
perbaikan dalam segi pelayanan. Begitu juga bidang pendidikan, guru wajib paham dan mengerti teknologi informasi. Dalam proses pembelajaran teknologi informasi bagi siswa menjadi daya tarik tersendiri yang bisa memacu semangat siswa dalam memahami materi yang diajarkan oleh guru.

Namun pada masa pandemic Covid-19 merebak di indonesia, bidang Pendidikan harus dilaksanakan secara daring dilaksanakan dari rumah oleh guru / dosen dan siswa / mahasiswa dengan memanfatkan aplikasi e-learning. Seluruh layanan administrasi di universitas dilaksanakan secara daring. Hal ini tentu harus ada penyegaran dalam pemahaman ilmu teknologi informasi bagi semua stakeholder.

Google adalah sebuah platform yang bisa dimanfaatkan dala melakukan pelayanan secara daring oleh stakeholder universitas kepada mahasiswa dan dosen. Beberapa aplikasi yang bisa digunakan adalah google meet dan google classroom sebagai aplikasi pembelajaran daring dan rapat daring, google drive sebagai penyimpanan, google map sebagai aplikasi mapping, google sheet, docs, slide sebagai pengganti aplikasi office, gmail untuk pengiriman surat secara daring, google form sebagai aplikasi kuisioner daring dan beberapa aplikasi pendukung lainnya.

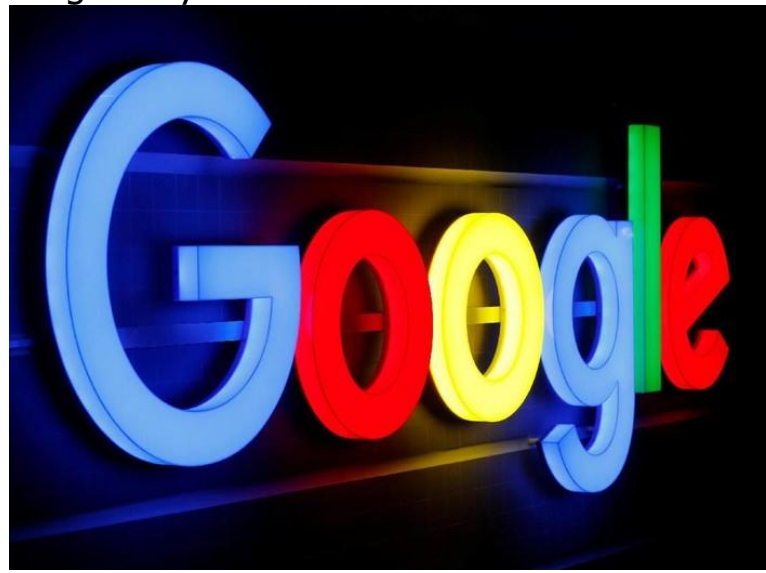

Gambar 1. Aplikasi Google

Pada sebuah jurnal yang ditulis (Gusteti et al., 2020) melakukan kegiatan yang senada dengan kegiatan pengabdian kepada masyarakat ini yang menggambil tema Pelatihan Membuat Video Pembelajaran Menarik Dengan Smartphone Pada Guru Adzkia. Dimana penulis jurnal dalam melaksanakan kegiatan pengabdian kepada masyarakat dengan memanfaatkan teknologi informasi dalam membuat sebuah media pembelajaran dengan menggunakan smartphone.

Hal lain juga dituliskan dalam jurnal yang ditulis oleh (Subekti \& Kurniawati, 2020) mengangkat tema yang tidak mempunyai perbedaan jauh pada jurnal sebelumnya. Pelaksanaan pengabdian kepada masyarakat dengan tema membuat materi bahan ajar sebagai penunjang pembelajaran secara daring.

Berbeda pada jurnal pengabdian kepada masyarakat yang ditulis oleh (Fitri et al., 2020) menjelaskan kegiatannya adalah melakukan edukasi kesehatan terhadap masyarakat yang tinggal berdekatan dengan tempat pembuangan akhir sampah di daerah cipayung. Hal ini dilakukan karena tingkat kerawanan penyebaran penyakit sangat tinggi untuk daerah tersebut. Dalam hal ini UPT Perpustakaan Universitas Lancang Kuning sebagai mitra pengabdian kepada masyarakat belum memiliki sumber daya manusia yang cakap dala penggunaan teknologi informasi dalam pelayana perpustakaan kepada civitas kampus.

Permasalah Mitra 
Alasan mengapa Pengabdian Kepada Masyarakat ini sangat perlu dilakukan adalah karena selama masa Pendemi Covid-19 semua layanan dialihkan secara daring. Termasuk layanan Perpustakaan di Universitas Lancang Kuning. Sedangkan pada prakteknya, pustakawan belum memiliki / mempunyai pengetahuan mumpuni dalam pengaplikasian layanan secara daring. Karena basic sarjana pustakawan bukan dari IT. Sedangkan sejak di terapkan Revolusi Industri 4.0 semua kegiatan beralih di control oleh mesin jauh sebelum Covid-19 datang.

\section{Solusi Ditawarkan}

Melihat pada keadaan ini team Pengabdian Kepada Masyarakat Universitas Lancang Kuning memandang perlu diadakan sosialisasi penggunaan aplikasi Google dalam meningkatkan pelayanan UPT Perpustakaan Universitas Lancang Kuning selama masa pandemic Covid-19. Sosialisasi ini berfokus membantu para pustakawan memahami, menggunakan dan memanfaatkan aplikasi google yang dapat mempermudah pekerjaan. Seperti layanan aplikasi google form yang bisa membantu mahasiswa dalam pengurusan administrasi surat menyurat. Begitu juga layanan email google yaitu Gmail juga dapat membantu layanan perpustakaan secara daring.

\section{Metode}

Pengabdian Kepada Masyarakat ini dilaksanakan di ruang Multimedia UPT Perpustakaan Universitas Lancang Kuning dengan metode seminar, praktek dan tanya jawab. Pelatihan dilakukan selama satu hari dimana peserta akan mendapatkan modul ajar untuk pelatihan, hal senada juga dijelaskan pada jurnal (Hardianto \& Wiza, 2020)(Hardiantio Roki, FC, Lucky Lhaura Van, 2019)(Roki Hardianto, Fajrizal, 2020).

Metode seminar dan tatap muka diberikan saat pemberian materi dengan menggunakan slide persentasi dan handout materi. Pada awal pertemuan para pustakawan akan diberikan praktek langsung tentang tingkat pemahaman kepada Teknologi Infromasi dan seputar aplikasi google. Pustakawan mencobakan langsung penggunaan dan melakukan sendiri penggunaan aplikasi google berupa google drive, google sheets, google meet, google doc dan lainnya. Metode evaluasi pencapaian target dilakukan pada awal dan akhir kegiatan. Hal ini untuk mengetahui tingkat pengetahuan peserta dan menerima masukan untuk perbaikan pada kegiatan kegiatan berikutnya. Secara rinci kegiatan pengabdian yang akan dilakukan sebagai berikut :

6. Kegiatan perkenalan

7. Pengenalan Teknologi Informasi dan aplikasi google

8. Pengisian kuisioner tentang penguasaan materi (pretraining)

9. Pendalaman materi pelatihan

10. Praktek langsung

11. Melakukan tanya jawab

12. Pengisian kuisioner tentang penguasaan materi (setelah training dilaksanakan)

Kegiatan ini menggunakan bebarapa perangkat pendukung di antaranya adalah :
5. Perangkat komputer / laptop
6. Modem internet / smartphone
7. Infocus

\section{Hasil dan Pembahasan}

Kegiatan dilaksanakan secara tatap muka dengan lama kegiatan adalah satu hari. Kegiatan dilaksanak di Gedung UPT Perpustakaan Universitas Lancang Kuning yang dihadiri oleh semua pustakawan sebanyak 10 peserta. Topik kegiatan tahap pertama 
adalah menjelaskan tentang peranan teknologi informasi kepada pustakawan UPT Perpustakaan Universitas Lancang Kuning. Hal ini karena pustakawan tidak mempunyai basic khusus dalam teknologi informasi walaupun dalam prakteknya pustakawan harus mampu memanfaatkan teknologi informasi dalam melaksanakan pekerjaan dan pelayanan kepada mahasiswa dan dosen yang berkunjung.

Tahap selanjutnya adalah menjelaskan tentang google dan aplikasi yang ada pada google yang bisa dimanfaatkan seperti :

1. Google Drive

Adalah aplikasi penyimpanan file secara cloud yang diberikan secara gratis dengan maksimal penyimpanan $15 \mathrm{~Gb}$.

2. Gmail

3. Google Meet

4. Youtube

5. Google Maps

6. Google Translate

7. Google Books

8. Google Doc

9. Google Sheets

10. Google Slide

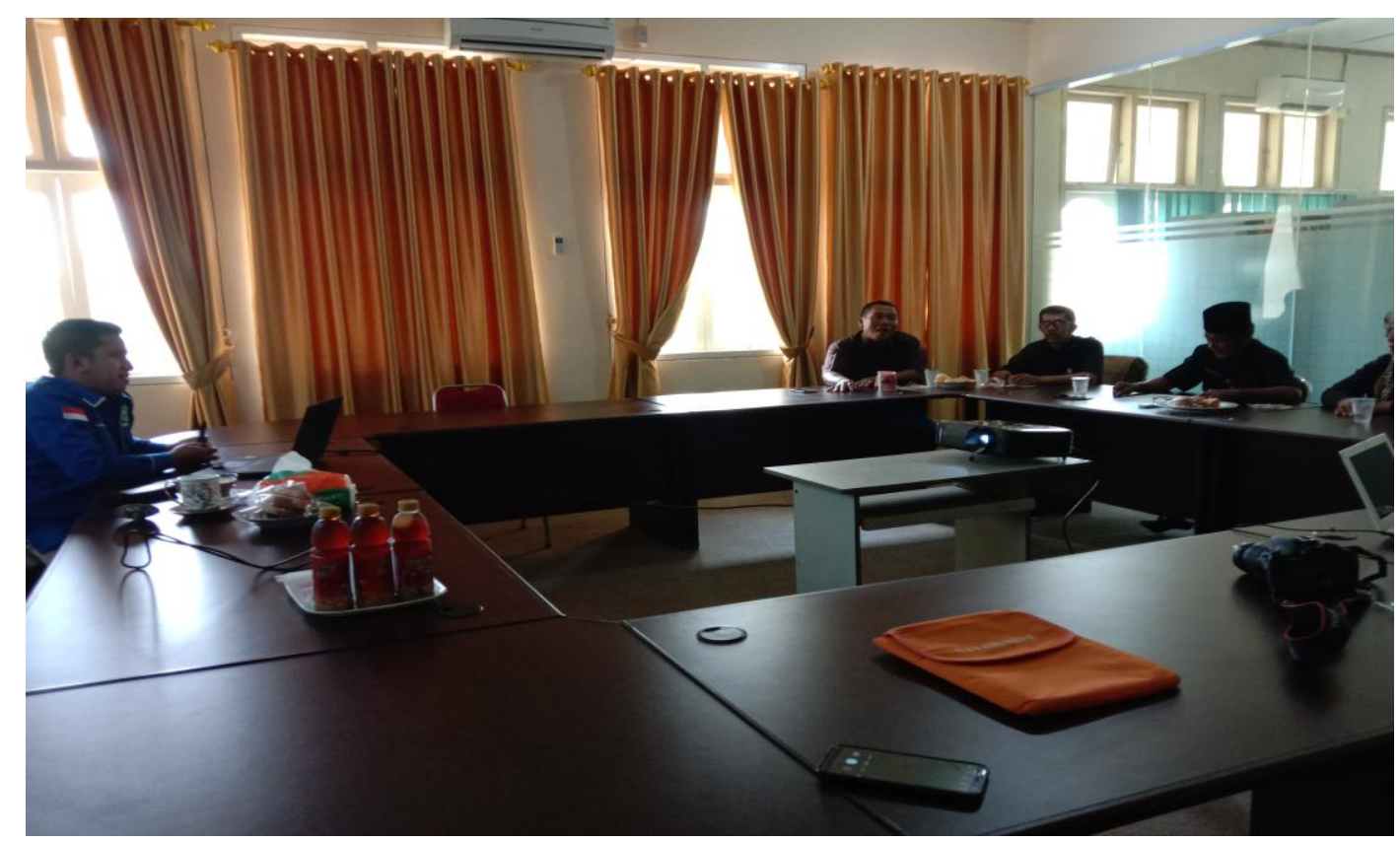

Gambar 2. Suasana saat pelatihan 


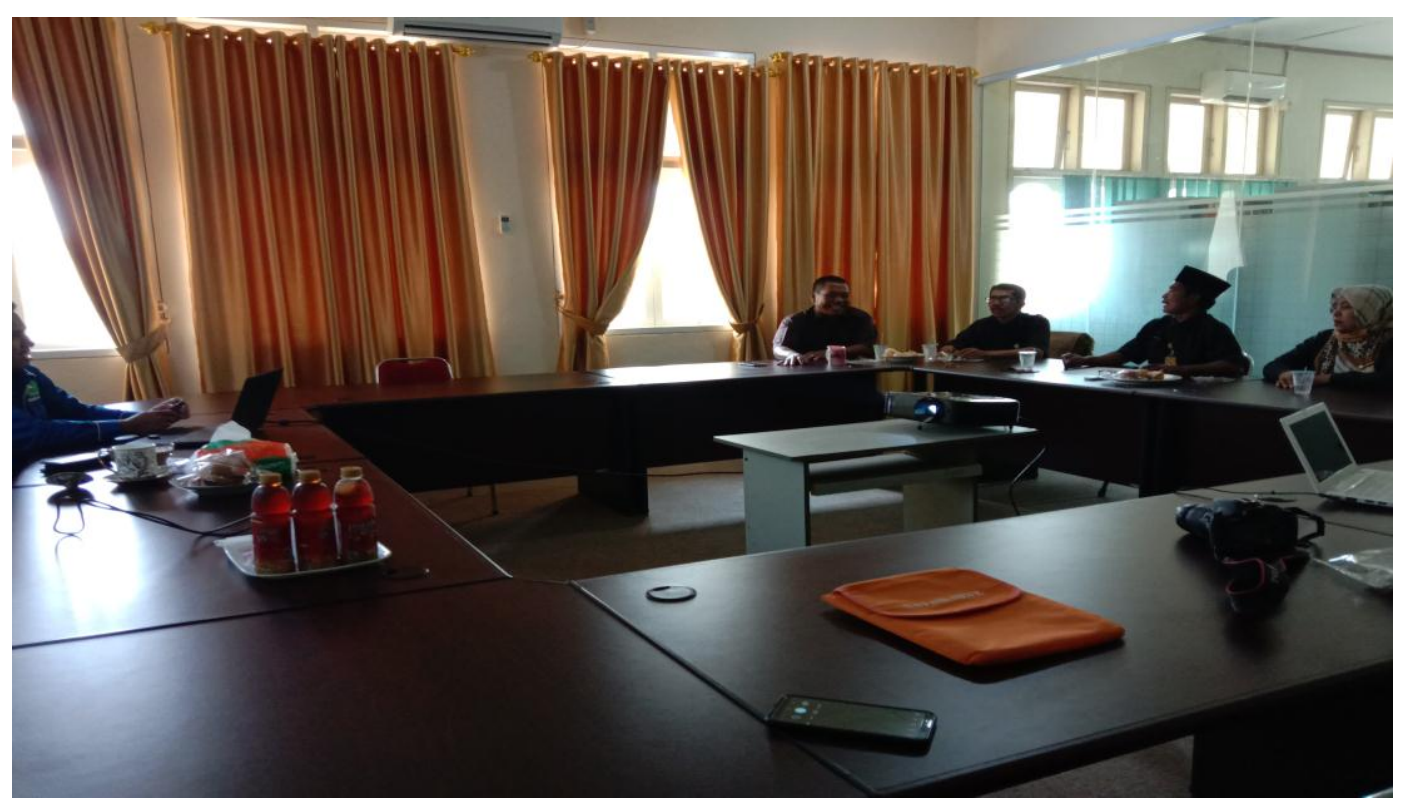

Gambar 3. Tanya jawab peserta dan pemateri

\section{Luaran Dicapai}

Luaran yang hendak dicapai dari kegiatan Pengabdian Kepada Masyarakat ini adalah berita kegiatan diterbitkan dalam portal berita online. Berita diterbitkan pada website Fakultas Ilmu Komputer Universitas Lancang Kuning www.fasilkom.unilak.ac.id. Berita terbit pada link https://fasilkom.unilak.ac.id/berita/detail/demi-tingkatkanpelayanan-selama-pandemi-covid19-pustakawan-unilak-ikuti-training-teknologi seperti gambar dibawah ini.
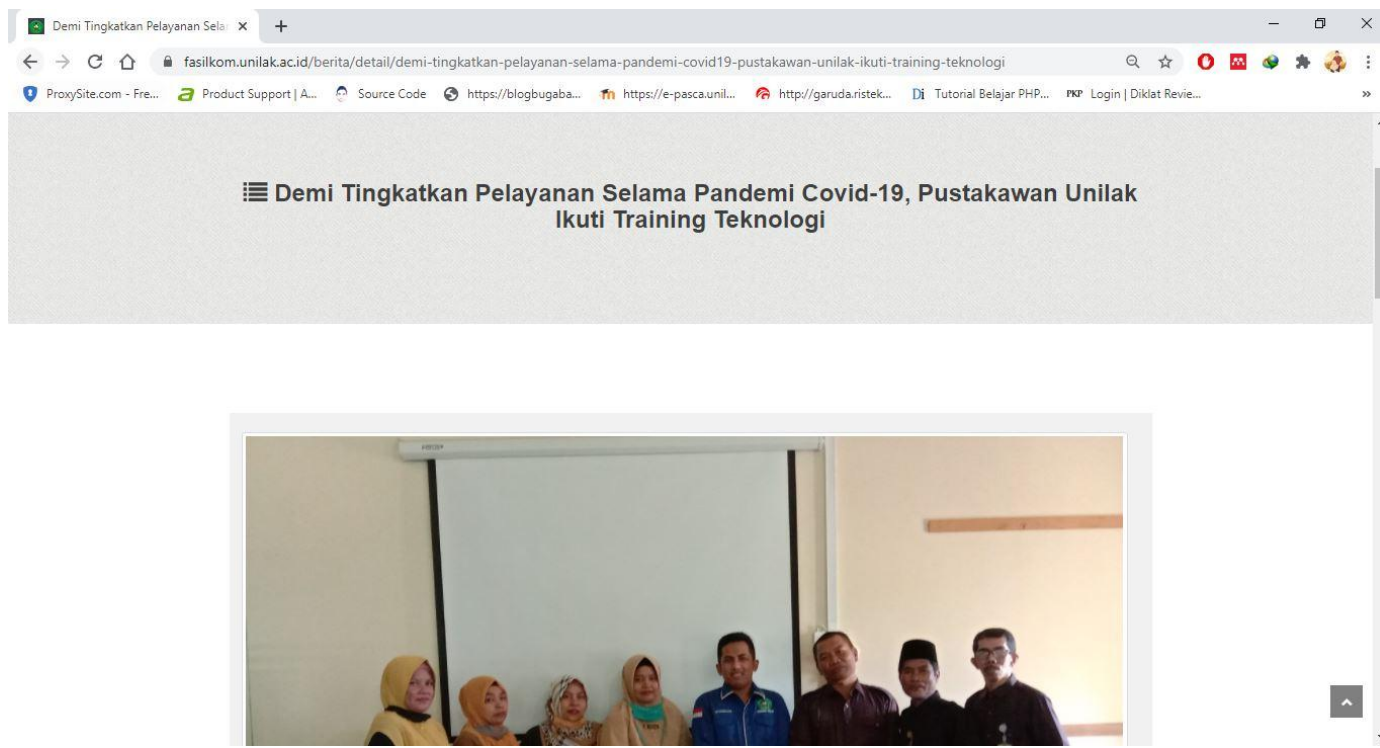

Gambar 4. Publikasi Berita Online Kegiatan PKM

Selain itu berita kegiatan PKM juga diterbitkan pada portal berita online www.uvdona.com. Berita diterbitkan pada link berita https://uvdona.com/demi- 
tingkatkan-pelayanan-selama-pandemi-covid-19-pustakawan-unilak-ikuti-training/ seperti gambar dibawah ini.

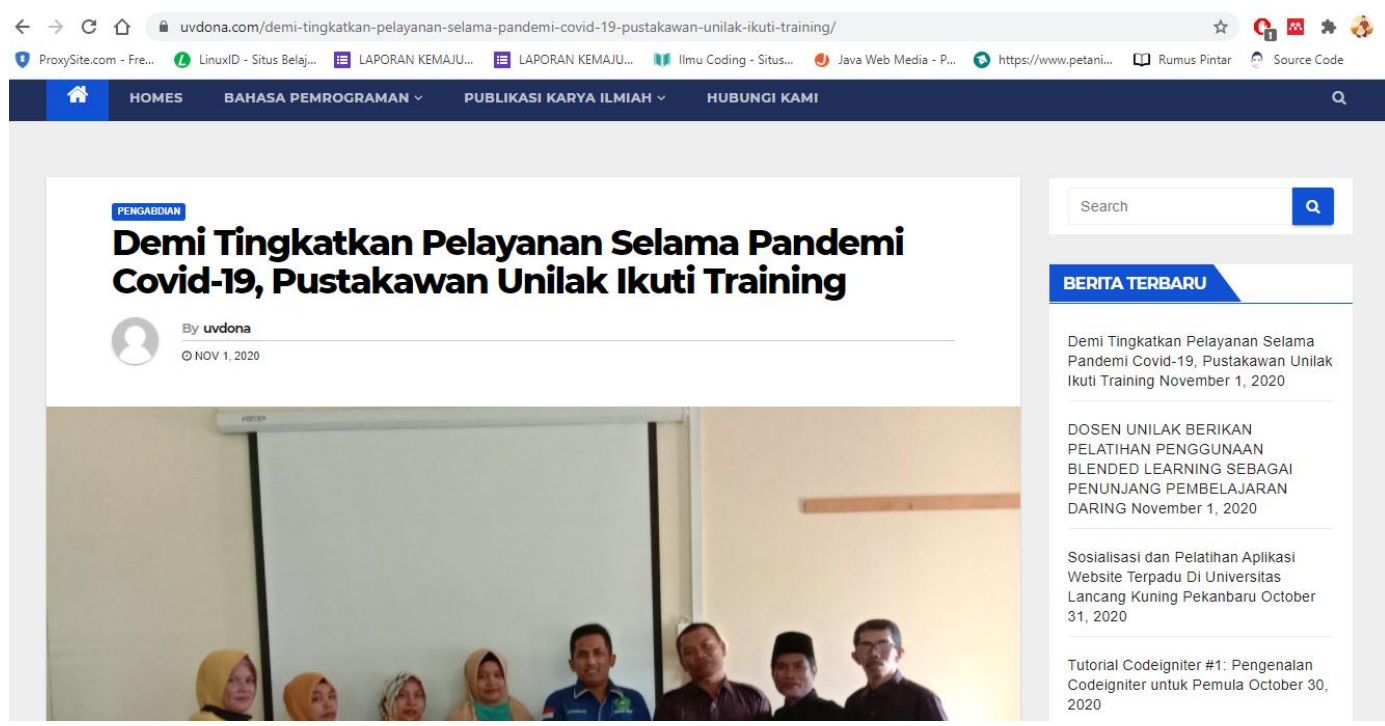

Gambar 5. Publikasi Berita Kegiatan PKM

Kegiatan Pengabdian Kepada Masyarat berupa berita diterbitkan pada portal berita online www.sapariau.com sebagai luaran dari kegiatan dapat dilihat pada link berita http://sapariau.com/berita/detail/demi-tingkatkan-pelayanan-selama-pandemi-covid19pustakawan-unilak-ikuti-training dengan cuplikan berita seperti gambar dibawah ini

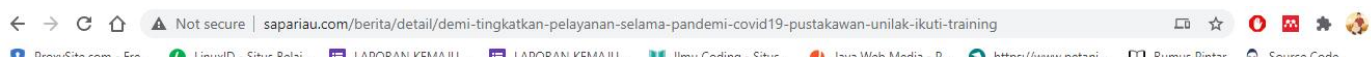
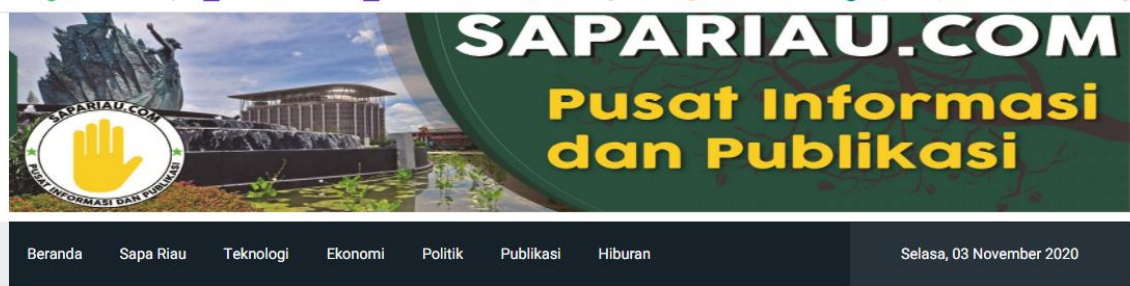

Demi Tingkatkan Pelayanan Selama Pandemi Covid-19,

Pustakawan Unilak Ikuti Training

Kontak Kami

Minggu, 01 Nov 2020, 16:13:04 WiB, 12 View, Kategori: Publikas
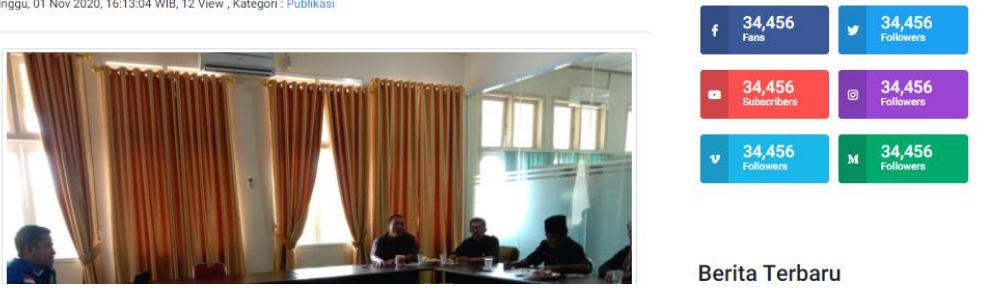

Gambar 6. Publikasi Berita Kegiatan PKM

\section{Kesimpulan}

Dari pelaksanaan kegiatan Pengabdian Masyarakat yang dilaksanakan di UPT Perpustakaan Universitas Lancang Kuning dapat dibuat kesimpulan sebagai berikut :

a. Kegiatan sangat bermanfaat oleh UPT Perpustakaan karena dapat menambah wawasan dari pustakawan terkait IT dalam proses layanan kepada mahasiswa, dosen atau masyarakat luas. 
b. Mengenalkan Pustakawan kepada aplikasi yang sangat menbantu dalam proses layanan pustaka, selama ini aplikasi tersebut sebenarnya sudah menjadi kebutuhan sehari

c. Pustawan sudah bisa menerapkan layanan daring selama pandemi Covid-19

d. Dengan penerapan layanan daring sangat membantu mahasiswa dan dosen dalam mengakses referensi tanpa harus datang ke Perpustakaan.

\section{Ucapan Terima Kasih}

Terimakasih diucapkan kepada Kepala UPT Perpustakaan Universitas Lancang Kuning atas dukungan pelaksanaan Pengabdian Kepada Masyarakat. Kemudian juga diaturkan ucapan terimakasih tak terhingga kepada rector Universitas Lancang Kuning yang telah memberikan dukungan melalui Lembaga Penelitian dan Pengabdian Masyarakat. Juga terimakasih kepada anggota tim pelaksana Dr. Junaidi, S.S,.M.Hum, Roki Hardianto, M.Kom dan Eddissyah Putra Pane, M.Kom. Semoga hasil dari pelaksanaan Pengabdian Masyarakat ini menjadi ibadah dan bermanfaat bagi masyarakat umum.

\section{Daftar Pustaka}

Fitri, A. M., Nurcandra, F., \& Pristya, T. Y. R. (2020). Pelatihan Upaya Kesehatan Kerja Bagi Masyarakat Cipayung Kota Depok. Dinamisia: Jurnal Pengabdian Kepada Masyarakat, 4(4), 605-610. Https://Doi.Org/10.31849/Dinamisia.V4i4.4366

Gusteti, M. U., Rahmalina, W., \& Desmariani, E. (2020). Pelatihan Membuat Video Pembelajaran Menarik Dengan Smartphone Pada Guru Adzkia 1). 4(1), 26-35.

Hardiantio Roki, Fc, Lucky Lhaura Van, \& F. W. (2019). Pelatihan Office Perkantoran Di Sma Pgri Pekanbaru Sebagai Bekal Menyonsong Revolusi Industri 4.0. DinamisiaJurnal Pengabdian Kepada Masyarakat, 3(1), 53-61.

Hardianto, R., \& Wiza, F. (2020). Sosialisasi Pengisian Sister Bagi Dosen Peserta Sertifikasi Pendahuluan Sister ( Sistem Informasi Sumbar Daya Terintegrasi ) Adalah Aplikasi Dari Kementerian Pendidikan Dan Kebudayaan Yang Bertujuan Mendata Dosen Se Indonesia . Didalam Sister Terdapat Riw. 4(1), 42-47.

Roki Hardianto, Fajrizal, Y. D. (2020). Pelatihan Menggunakan Sistem Informasi Geografis Lokasi Lembaga Swadaya Masyarakat Di Kesbangpol Pekanbaru. Jurnal Pengabdian Masyarakat Multidisiplin, 3(2), 78-85. Https://Doi.Org/10.36341/Jpm.V3i2.1006

Subekti, A. S., \& Kurniawati, L. A. (2020). Pelatihan Mendesain Pembelajaran Daring Menarik Selama Pandemi Covid-19 Dengan Teknologi Pembelajaran Sederhana. Dinamisia: Jurnal Pengabdian Kepada Masyarakat, 4(4), 588-595. Https://Doi.Org/10.31849/Dinamisia.V4i4.4679 